\title{
Distribution Pattern of Cave Entrance Based on Morphometry in Gunung Sewu Karst Landscape
}

\author{
Ridwan Arif Pambudi ${ }^{1}$, Astrid Damayanti ${ }^{2 *}$, Kuswantoro Marko ${ }^{2}$ \\ ${ }^{1}$ Bachelor Program of Geography; Faculty of Mathematics and Natural Sciences; Universitas Indonesia; Depok-Indonesia \\ ${ }^{2}$ Department of Geography; Faculty of Mathematics and Natural Sciences; Universitas Indonesia; Depok-Indonesia
}

\begin{abstract}
Wonosari-Punung Formation of Middle Miocene-Pliocene and Semilir Formation of Early-Middle Miocene consists of Gunung Sewu Karst Landscape in Ponjong and Semanu District; Gunungkidul Regency. Gunung Sewu Karst Landscape has advanced karstification so that the morphology of exokarst and endokarst could be formed. Cave entrance as a marker of the endokarst morphology existence is formed by varying morphometry. This research aims to determine cave entrance distribution pattern based on a cave entrance morphometry. These research variables are cave entrance morphometry; geological formation; and geological structure (geological lineament). The analytical method uses nearest neighbour analysis (NNA) and lineament analysis. The result of this research shows that vertical cave entrance with oval; narrow; and irregularity shape have dispersed distribution pattern in Wonosari-Punung Formation. Horizontal cave entrance with irregular; rectangular; narrow; and an oval shape; have clustered pattern of distribution in the Wonosari-Punung and Semilir Formations. This research is used as a preliminary study for the development of underground water resources that are commonly found in caves of Gunung Sewu Karst Landscape.
\end{abstract}

Keywords: cave entrance; distribution pattern; lineament analysis; morphometry; nearest neighbour analysis.

\section{Introduction}

Gunung Sewu Karst Landscape at Ponjong and Semanu Districts consists of Wonosari-Punung Formation (Tmwl), Semilir Formation (Tms), and Oyo Formation (Tmo)[1].However, the percentage of Oyo Formation is $0,2 \%$, it is very small compared to the two other formations that compose Gunung Sewu Karst Landscape[1A]. The Wonosari-Punung Formation (Tmwl) was formed during the Middle Miocene-Pliocene in shallow marine environment, while the Semilir Formation was formed during the Early-Middle Miocene in the deepwater environment that eventually turned into land [2].

Gunung Sewu Karst Landscape is the result of tectonic, erosion, denudation, and deposition activity occurring since Miocene [3]. Gunung Sewu Karst Landscape has advanced karstification until reaching mature genesis stadium.It can be seen from the existence of endokarst morphology (cave)[4]. Cave entrance as a marker of the endokarst morphology existence is formed by varying morphometry [5].Zhou et al., (2017) have conducted research on the cave entrance distribution pattern in Guizhou (China), the result, cave entrance distribution in Guizhou is influenced by rock layers, properties, formations, and hydrology [6].

It is estimated that $20-25 \%$ of the world's population depend on the presence of water in the karst landscape [7]. However, high secondary porosity and permeability in the karst landscape impacts on the high rate of water infiltration to saturation zone, it has an impact on the lack of surface water [4]. Generally, the water which is infiltrating into such a layer of carbonate rock can be found in the cave canal [5]. This research aims to determine cave entrance distribution pattern based on a cave entrance morphometry. This research is used as a preliminary study for the development of underground water resources that are commonly found in caves of Gunung Sewu Karst Landscape. The utilization of underground water resources in Gunung Sewu Karst Landscape that can sufficient of community needs have a significant role in reducing the utilization of fossil fuel on water transport from non-karst area to karst area during the dry season. Therefore, this research participate to create a low carbon society.

\section{Materials and methods}

\subsection{Study area}

This research is conducted at Gunung Sewu Karst Landscape, specifically at Ponjong and Semanu Districts, Gunungkidul Regency, Special Region of Yogyakarta. (Fig 1). Gunung Sewu Karst Landscape on Ponjong and Semanu Districts has an unconformity above Panggung Massif Geomorphological Region, which results in a gradual morphology from the structural volcanic hill on the north and becomes karst hill on the south [8,9]. Gunung Sewu Karst Landscape is a kind of tropical karst landscape [10]. Gunung Sewu Karst Landscape is affected by monsoon rain type with clear difference characteristic between wet and dry season in a year with one peak of wet season. (Fig 2).

*Corresponding author: astrid.damayanti@ sci.ui.ac.id 


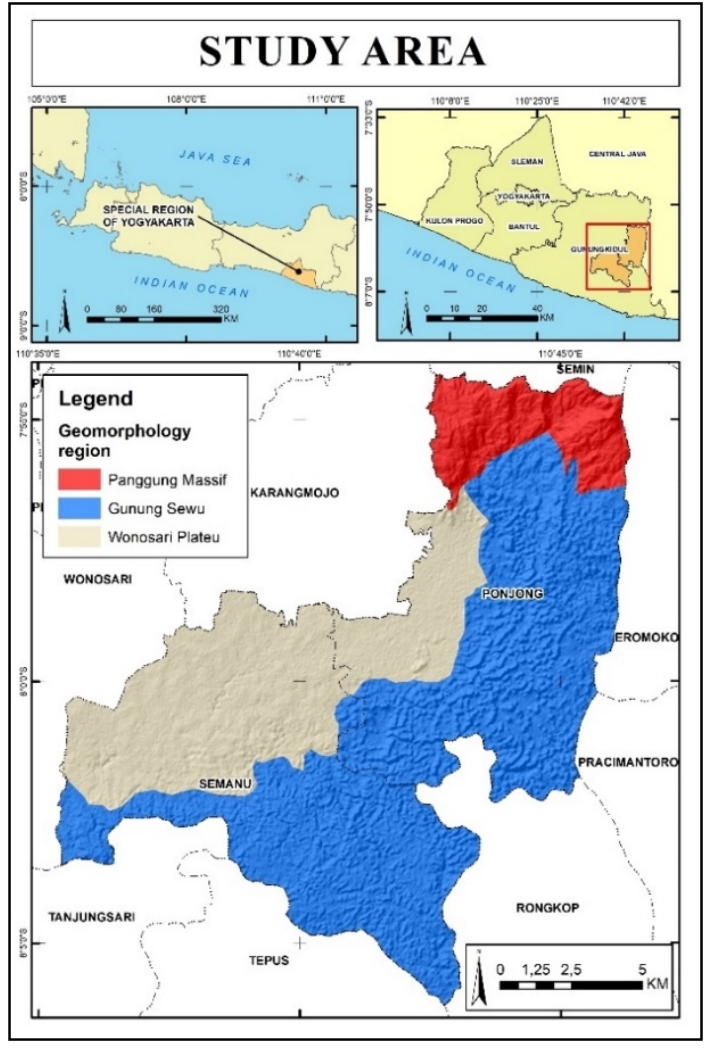

Fig. 1. Map of Study Area Location

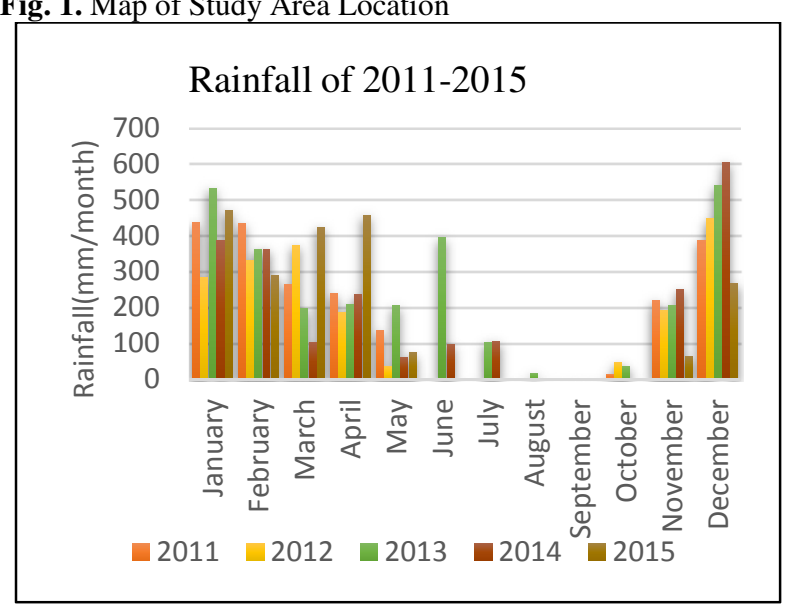

Fig. 2. Rainfall Chart of 2011-2015

\subsection{Materials}

This research consists of three variables, that are, cave entrance morphometry, geological formation (lithology), and geological structure (lineament). Cave entrance morphometry consists of type, shape, and measure of the cave entrance. Cave entrance type is divided into vertical and horizontal cave entrance types [5]. Cave entrance shape is divided into oval, irregular, narrow, and rectangular $[5,11,12]$. Cave entrance measure is the result of area measurement with a meter square $\left(\mathrm{m}^{2}\right)$ unit using the modification of closed polygon and offset methods; and using Google Earth software [13]. Lithology is acquired from Surakarta and Giritontro Geology Map with a scale of 1:100.000 from The Center of Geology Research and Development, Geology Agency, Energy and Mineral Resource Ministry [1]. Geological structure (lineament) is acquired from Sentinel 1 satellite imagery that is acquired on January $26^{\text {th }}, 2018$ with path/frame 127/1151 and spatial resolution of 10 meters from European Space Agency (https://vertex.daac.asf.alaska.edu) [14].

\subsection{Methods}

Field survey is conducted to obtain cave entrance morphometry. Vertical cave entrance with a large area is measured by the tool of measurement area from Google Earth software, meanwhile small vertical cave entrance is measured by closed polygon method (Fig 3a). Horizontal cave entrance is measured by offset method (Fig 3b). Data of cave entrance morphometry thatis acquired is further processed using Topodroid and Autocad software to determine the measure of area. All data of cave entrance morphometry is then inputed to each cave entrance attributes.

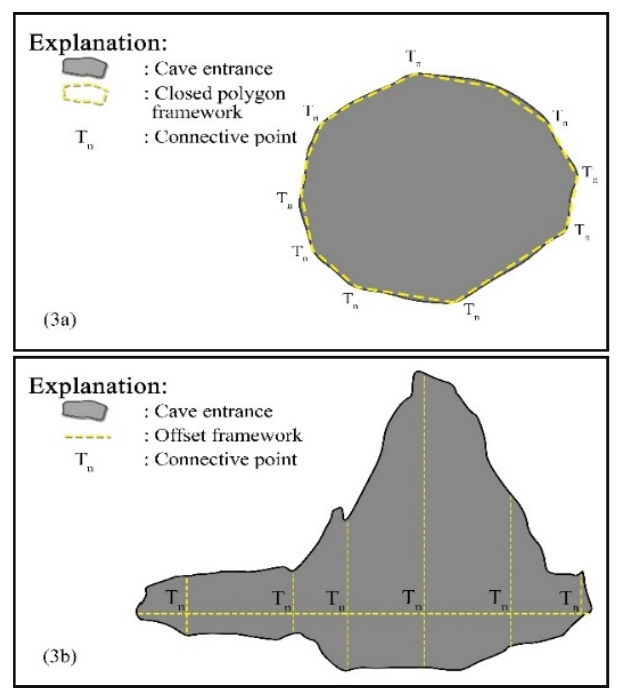

Fig. 3. Sketch of Cave Entrance Measurement Methods (3a) Closed Polygon ( $3 b$ ) Offset.

The lineament is obtained by an automatic lineament extraction from Sentinel 1 satellite imagery using PCI Geomatica 2017 software. The pre-processing phase for this satellite imagery is a filter (Filter Lee) to eliminate the speckle effect and orthorectification (Range Dopler Orthorectification) to eliminate geometric distortion. Furthermore, extraction is done by using the "line" algorithm that consists of six parameters (Table 1) [15]. Lithology from Surakarta and Giritontro Geology Map with a scale of 1:100.000 is obtained by geo-referencing and re-digitizing.

Table 1. The Parameters and Applied Values of Line

Algorithm on PCI Geomatica [15]
\begin{tabular}{|l|c|}
\hline Parameters & Applied values \\
\hline RADI & 5 \\
\hline GTHR & 55 \\
\hline LTHR & 10 \\
\hline FTHR & 2 \\
\hline ATHR & 20 \\
\hline DTHR & 20 \\
\hline
\end{tabular}

The analytical method that is used in this research is nearest neighbour analysis and lineament analysis. The 
nearest neighbour analysis is calculated based on the distance of each cave entrances with their nearest neighbour point (Formula 1). The result of the nearest neighbour analysis consists of three patterns, that are clustered, dispersed, and random. These patterns determined based on the nearest neighbour ratio value. The dispersed pattern has a ratio value of almost 2,15 , the random pattern has a ratio value of almost 1 , and the clustered pattern has a ratio value of almost 0 (Fig 4 ). The nearest neighbour analysis in this research is conducted using ArcMap 10.4 software.

$$
T=\frac{J u}{J h}
$$

\section{Explanation}

$\mathrm{T}=$ nearest neighbour distribution index.

$\mathrm{Ju}=$ the average nearest distance measured between a point with other neighbours.

$\mathrm{Jh}=$ the average distance obtained from all points.

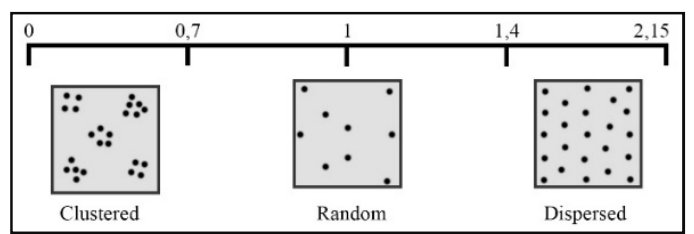

Fig. 4. Range of Nearest Neighbour Index Value

The distribution pattern of cave entrance based on lineament analysis is analyzed using the result of Sentinel 1 lineament extraction. The analysis is done by overlaying between the coordinate point of the cave entrances with the buffer zone of lineament as far as 50 meters. The distance of a buffer zone is considered based on diagonal distance of moderate doline [6].From this analysis result, it is known that the distribution pattern of cave entrance is based on the geological structureit controls.

\section{Result and Discussion}

\subsection{Distribution Pattern of Vertical Cave Entrance}

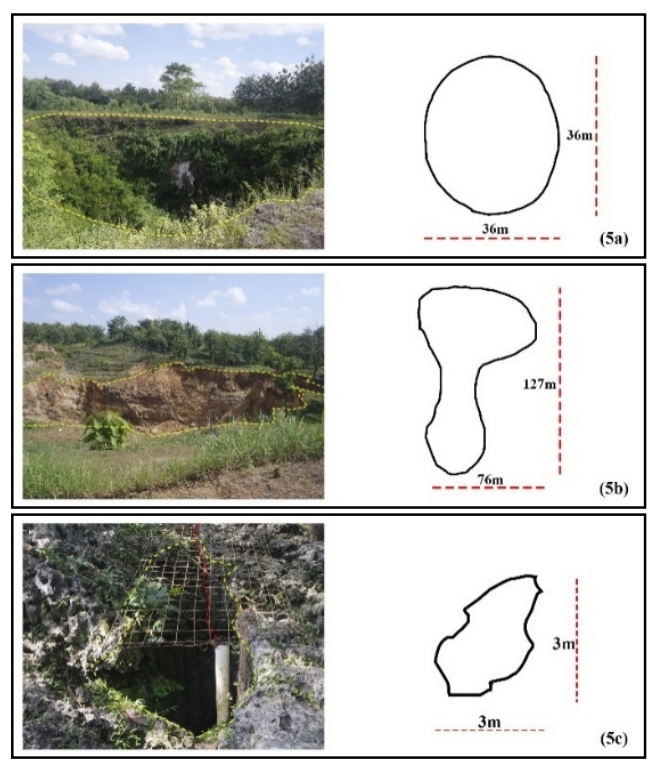

Fig. 5. Shapes of Vertical Cave Entrances
Vertical cave entrances at Ponjong and Semanu Districts consists of three shapes, that are oval, irregular, and narrow. The oval vertical cave entrances measures from 4,19-2.089 $\mathrm{m}^{2}$ (Fig 5a). The irregular vertical cave entrance measures from $7.558 \mathrm{~m}^{2}$ (Fig $5 \mathrm{~b}$ ). The narrow vertical cave entrances measures from 3,82-6,29 $\mathrm{m}^{2}$ (Fig $5 \mathrm{c})$. Based on the shape and measurement data of vertical cave entrance, there is a tendency that the narrow vertical cave entrances have smaller measures than the oval and irregular vertical cave entrances (Table 2).

Table 2. Shape and Size of Vertical Cave Entrances

\begin{tabular}{|c|c|c|l|}
\hline Shape & Size $\mathbf{( m}^{\mathbf{2}} \mathbf{)}$ & Code & \multicolumn{1}{|c|}{ Cave Name } \\
\hline Oval & 4,2 & 3 & Luweng Bendo \\
\cline { 2 - 4 } & 333 & 5 & Luweng Ciut \\
\cline { 2 - 4 } & 1.412 & 6 & Luweng Jomblang \\
\cline { 2 - 4 } & 1.501 & 8 & Luweng Jubleng \\
\cline { 2 - 4 } & 2.089 & 2 & Luweng Bedoyo \\
\hline Irregular & 7.558 & 7 & Luweng Blimbing \\
\hline Narrow & 3,8 & 9 & Luweng Ledok \\
\cline { 2 - 4 } & 5,7 & 1 & Luweng Cokro \\
\cline { 2 - 4 } & 6,3 & 4 & Luweng Ceblok \\
\hline
\end{tabular}

The nearest neighbour analysis towards nine vertical cave entrances at Ponjong and Semanu Districts results in a nearest neighbour analysis ratio value of 1,46 and $\mathrm{z}$ score of 2,67 . This nearest neighbour ratio shows that vertical cave entrances have a dispersed distribution pattern. However, z-score of 2,67 indicates the probability of less than $1 \%$ of dispersed distribution members also has random distribution pattern.

This nearest neighbour analysis can be visualized by using a buffer zone as far as 2.960 meters. The distance of the buffer zone is considered based on the rounding of the average nearest distance of each vertical cave entrances of 2.966,93 meters. As a result, there is a dispersed and random pattern in the vertical cave entrances distribution pattern. Nevertheless, dispersed pattern distribution dominates the vertical cave entrance distribution pattern (Fig 6). The vertical cave entrances that are distributed randomly are the entrances of Luweng Cokro Cave (1).

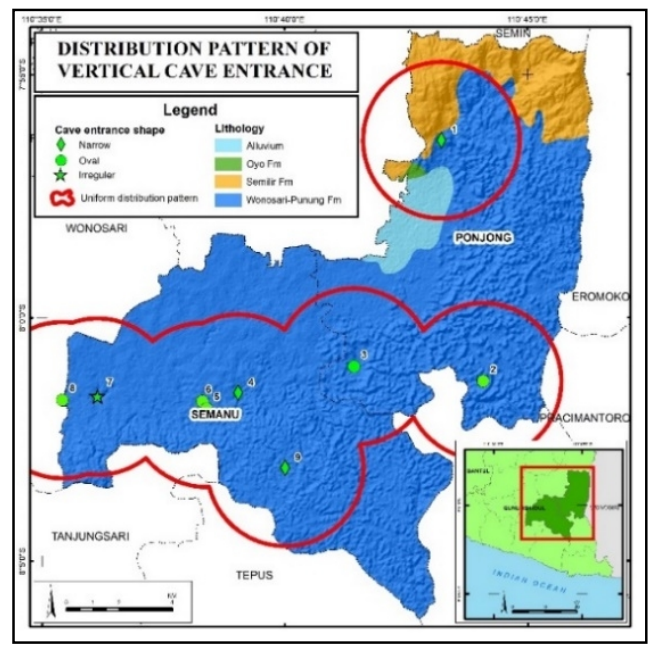

Fig. 6. Distribution Pattern of Vertical Cave Entrance Based on Nearest Neighbour Analysis 
Based on the lineament analysis, nine vertical cave entrances at Ponjong and Semanu Districts are located within 50 meters from the buffer zone (Fig 7). It indicates that all vertical cave entrances have a dispersed distribution pattern. It shows that the vertical cave entrance distribution pattern at Ponjong and Semanu Districts is affected by the geological lineament.

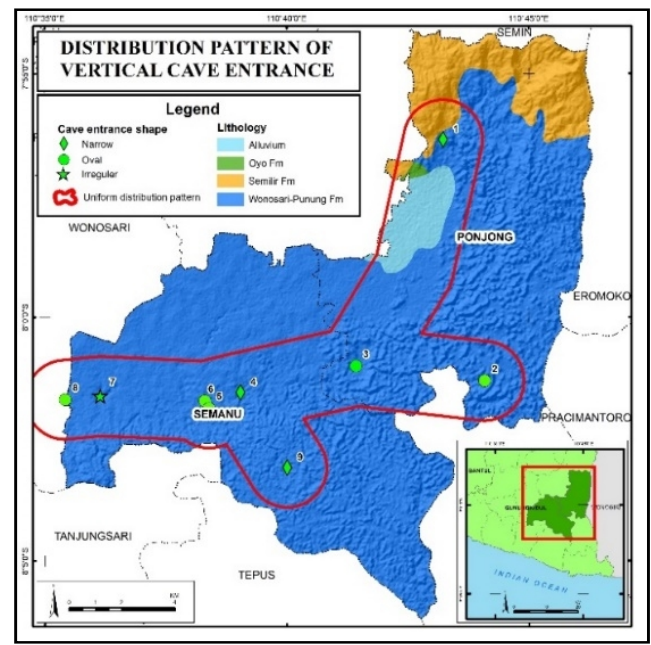

Fig. 7. Distribution Pattern of Vertical Cave Entrance Based on Lineament Analysis

\subsection{Distribution Pattern of Horizontal Cave Entrance}

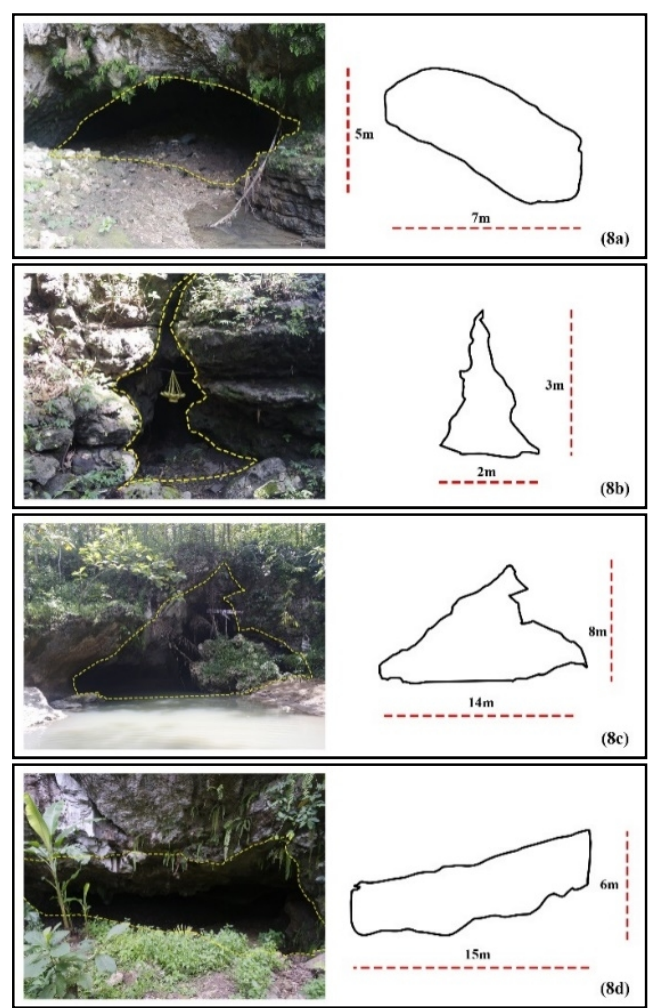

Fig.8. Shape of Horizontal Cave Entrances

Horizontal cave entrances at Ponjong and Semanu Districts consists of four shapes; narrow, oval, rectangular, and irregular. The oval horizontal cave entrances measures from 20,5-141,5 $\mathrm{m}^{2}$ (Fig 8a). The narrow horizontal cave entrances measures from 2,3-31,4 $\mathrm{m}^{2}$ (Fig 8b). The rectangular horizontal cave entrances measures from 2,5-276,6 $\mathrm{m}^{2}$ (Fig 8c). The irregular horizontal cave entrances measures from 5,2-746,6 $\mathrm{m}^{2}$ (Fig 8d).

Based on the shape and measure data of horizontal cave entrances, there is the tendency that oval and narrow horizontal cave entrances have smaller measure than rectangular and irregular horizontal cave entrances (Table 3). Nearest neighbour analysis of 24 horizontal cave entrances at Ponjong and Semanu Districts results in the nearest neighbour ratio value of 0,64 and $z$-score of $-3,36$. The nearest neighbour ratio value indicates that the horizontal cave entrances have a clustered distribution pattern. However, the $\mathrm{z}$-score of $-3,36$ indicates a possibility of less than $1 \%$ that horizontal cave entrance with the clustered distribution pattern also have random distribution pattern.

Table 3. Shape and Size of Horizontal Cave Entrances

\begin{tabular}{|c|c|c|c|}
\hline Shape & Size $\left(\mathbf{m}^{2}\right)$ & Code & Cave name \\
\hline \multirow[t]{2}{*}{ Oval } & 20,5 & 31 & Ngingrong 2 \\
\hline & 141,5 & 29 & Seropan 2 \\
\hline \multirow[t]{4}{*}{ Narrow } & 2,3 & 16 & Luweng \\
\hline & 7,9 & 27 & Karanglampar \\
\hline & 21,8 & 28 & Wot Lemah \\
\hline & 31,4 & 33 & Sodong \\
\hline \multirow[t]{9}{*}{ Rectangular } & 2,5 & 21 & Sangupati \\
\hline & 24,55 & 19 & Sinden \\
\hline & 29,1 & 32 & Tong Pocot \\
\hline & 30,8 & 24 & Jurug \\
\hline & 37,1 & 20 & Kali Ngereneng \\
\hline & 45,8 & 26 & Song Karang \\
\hline & 53,1 & 10 & Grudo \\
\hline & 70,8 & 11 & Grembel \\
\hline & 276,6 & 30 & Ngingrong 1 \\
\hline \multirow[t]{9}{*}{ Irregular } & 5,2 & 12 & Saptoargo \\
\hline & 17,1 & 13 & Tlogo \\
\hline & 30 & 18 & Seropan 1 \\
\hline & 31,1 & 22 & Toto \\
\hline & 36 & 25 & Bribin \\
\hline & 75,8 & 14 & Gremeng \\
\hline & 203,6 & 23 & Kali Suci \\
\hline & 218,2 & 17 & Jlamprong \\
\hline & 746,6 & 15 & Song Gilap \\
\hline
\end{tabular}

This nearest neighbour analysis distribution pattern can be visualized by using a buffer zone as far as 980 meters. The 980-meter-long buffer zone distance is determined based on the average distance of the nearest neighbour, which is 979,9 meters. As a result, there are clustered and random distribution pattern of horizontal cave entrances at Ponjong and Semanu Districts. However, the clustered distribution pattern is more dominant (Fig 9). The horizontal cave entrances that are distributed randomly based on nearest neighbouranalysis is the entrance of Song Gilap Cave (15), Tong Pocot (32), and Sodong (33). 


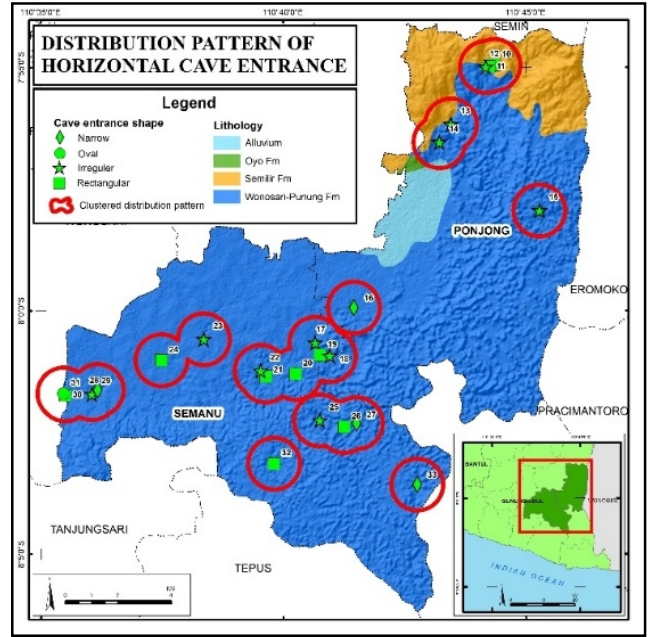

Fig. 9. Distribution Pattern of Horizontal Cave Entrance Based on Nearest Neighbour Analysis

Based on the lineament analysis, 21 horizontal caves entrances are located within 50 meters of buffer zone (Fig 10). The three cave entrances that are not in the buffer zone is the entrance of Cave Jurug (24), Jlamprong (17), and Sinden (19). Based on the lineament analysis, it can be seen that horizontal cave entrance at Ponjong and Semanu Districts is dominated by clustered distribution pattern. These results of lineament analysis indicate the distribution pattern of the horizontal cave entrances affected by the lineament.

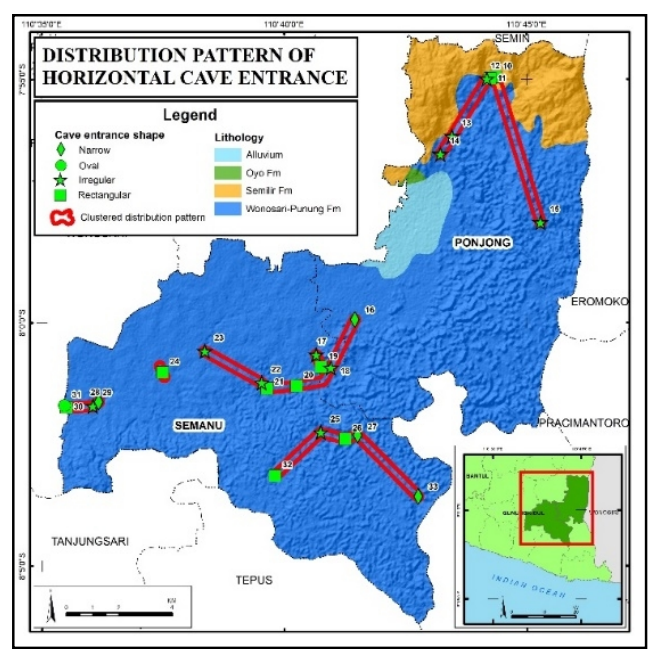

Fig. 10. Distribution pattern of horizontal cave entrance based on lineament analysis

\section{Conclusion}

Based on the nearest neighbour analysis, vertical cave entrances have a dispersed distribution pattern in Wonosari-Punung Formation with the nearest neighbour ratio value of 1,46 and cave entrance with oval shape which measures from 4,2-2.089 $\mathrm{m}^{2}$, narrow shape which measures from $3,8-6,3 \mathrm{~m}^{2}$, and irregular shape which measures from $7.558 \mathrm{~m}^{2}$. Horizontal cave entrances have more varied clustered distribution pattern in WonosariPunung Formation and Semilir Formation with the nearest neighbour ratio value of 0,64 and cave entrance with irregular shape which measures from5,2-746,6 $\mathrm{m}^{2}$, rectangular shape which measures from 2,5-276,6 $\mathrm{m}^{2}$, narrow shape which measures from 2,3-31,4 $\mathrm{m}^{2}$, and oval shape which measures from 20,5-141,5 $\mathrm{m}^{2}$. The distribution pattern of vertical and horizontal cave entrances are affected by the existence of geological lineament.

Thanks are due to Directorate of Research and Community Service (DRPM) Universitas Indonesia that has supported this research in form of Hibah PITTA with contract number of 2236/UN2.R3.1/HKP.05.00/2018.

\section{References}

1. Surono, Sudarno I and Toha B., Peta Geologi Lembar Surakarta-Giritontro, skala 1:100.000. (1992)

2. Surono, Litostratigrafi Pegunungan Selatan Bagian Timur Daerah Istimewa Yogyakarta dan Jawa Tengah J.S.D.Geol19 31-43 (2009)

3. Kusumayudha S B, Setiawan J, Ciptahening A N and Septianta P D., Geomorphologic Model of Gunungsewu Karst, Gunung Kidul Regency, Yogyakarta Special Territory, Indonesia: The Role of Lithologic Variation and Geologic Structure J. Geol. Resour. Eng.3 1-7 (2015)

4. Kusumayudha S. B., Mengenal Hidrogeologi Karst (Yogyakarta: Pusat Studi Karst LPPM UPN Veteran Yogyakarta) (2004)

5. Culver D C and White W. B.,Encyclopedia of Caves (California: Elsevier Inc.) (2005)

6. Zhou Z, Zhang S, Xiong K, Li B, Tian Z, Chen Q, Yan L and Xiao S., The spatial distribution and factors affecting karst cave development in Guizhou Province J. Geogr. Sci.27 1011-24 (2017)

7. Ford D and Williams P.,Karst Hydrogeology and Geomorphology (Chichester: John Wiley \& Sons Ltd) (2013)

8. Husein $\mathrm{S}$ and Srijono, Tinjauan geomorfologi Pegunungan Selatan DIY/Jawa Tengah: telaah peran faktor endogenik dan eksogenik dalam proses pembentukan pegunungan Pros. Work. Geol. Pegunungan Selatan 2007 19-19 (2009)

9. Van Bemmelen R. W., The Geology of Indonesia. General Geology of Indonesia and Adjacent Archipelagoes Geol. Indonesia. Volume IA 637-44 (1949)

10. Sweeting M M., Karst Landforms (London: Macmillan) (1972)

11. Mylroie J E and Carew J L., Karst development on carbonate islands Speleogenes. Evol. Karst Aquifers 55-76 (2003)

12. White W.B., Geomorphology and Hydrology of Karst Terrains (Cambridge: Cambridge University Press) (1988)

13. Laksmana E. E., Stasiun Nol: Teknik-Teknik Pemetaan dan Survei Hidrologi Gua (Yogyakarta: Acintyacunyata Spleological Club) (2016)

14. European Space Agency. ESA Sentinel 1 Handbook Eur. Sp. Agency Tech. note 1-80 (2013) 
15. Adiri Z, El Harti A, Jellouli A, Lhissou R, Maacha L, Azmi M, Zouhair M and Bachaoui E M., Comparison of Landsat-8, ASTER and Sentinel 1 satellite remote sensing data in automatic lineaments extraction: A case study of Sidi Flah-Bouskour inlier, Moroccan Anti Atlas Adv. Sp. Res.60 2355-67 (2017) 